\title{
Reconstructing the History of Machado-Joseph Disease
}

\author{
Alex Tiburtino Meira ${ }^{a}$ José Luiz Pedroso ${ }^{b}$ François Boller ${ }^{c}$ \\ Gustavo Leite Franklina Orlando Graziani Povoas Barsottini ${ }^{\text {b }}$ \\ Hélio Afonso Ghizoni Teive ${ }^{a}$ \\ aDepartamento de Medicina Interna, Universidade Federal do Paraná, Curitiba, Brazil; bUniversidade Federal de São \\ Paulo, Departamento de Neurologia, São Paulo, São Paulo, Brazil; 'Department of Neurology, George Washington \\ University Medical School, Washington, DC, USA
}

\section{Keywords}

Machado-Joseph disease - History of neurology .

Spinocerebellar ataxia type 3 - Dominant spino-pontine atrophy

\section{Abstract}

Machado-Joseph disease (MJD), or spinocerebellar ataxia type 3 , was originally described in members of the families of Machado, Thomas, and Joseph from São Miguel Island, Azores, Portugal, in 1972. The purpose of this article is to present previous descriptions of hereditary ataxia resembling the heterogeneous phenotypic intra-familiar presentation of MJD. We suggest that the condition would best be called dominant spino-pontine atrophy.

(c) 2020 S. Karger AG, Basel

\section{Introduction}

Machado-Joseph disease (MJD), or spinocerebellar ataxia type 3 (SCA 3), was originally described in members of the families of Machado (William Machado) [1], Thomas [2], and Joseph, actually in the descendants of
Antone Joseph [3], from São Miguel Island, Azores, Portugal. In the beginning, it was called the Azorean disease [4], nigro-spino-dentatal degeneration with nuclear ophthalmoplegia [2], or autosomal dominant striatonigral degeneration [3]. William Machado was Azorean Portuguese. Some of his children emigrated to Massachusetts, mainly in the southeastern part of the state, in the late 19 th and early 20th centuries. The original description is made based upon 6 hospitalized members of the family, and other 30 were examined too, and 35 other affected family members were not examined, including William Machado and his wife [1]. Antone Joseph, on the other hand, was an Azorean immigrant to the USA in 1845, and the disease developed in him and in other 51 of his descendants, although only 13 of them were examined by the authors, including a neuropathological description of case 1 .

In 1977, a Portuguese neurologist, Paula Coutinho (1941-), described a disease from Azorean people, with multiple phenotypic characteristics [5], which in fact was the same disease reported previously in the USA, by the authors cited. At that time, the disease was classified into 3 types: type 1, pyramidal and extrapyramidal (15\%); type 2 , pyramidal and cerebellar (38\%); and type 3, cerebellar karger@karger.com www.karger.com/ene

(c) 2020 S. Karger AG, Basel

Karger"
Dr. Hélio Afonso Ghizoni Teive

Movement Disorders Unit, Neurology Service, Internal Medicine Departmen Hospital de Clínicas, Federal University of Paraná, General Carneiro 1103/102 Curitiba, PR 80060-150 (Brazil)

hagteive@mps.com.br 
with distal symmetric muscular atrophy (47\%) [6]. In 1980, Coutinho et al. [7] named it Machado-Joseph disease, honoring the first patients and descendants who suffered from the disease (not the doctors who described it previously), and she also described the diagnostic criteria for the disease $[7,8]$. Worldwide distribution of the disease seems to be associated with the gene diffusion during the Portuguese Great Navigation Era followed by migratory settlement [8].

This entity has the characteristic of presenting with a wide clinical variation. The age of MJD onset is usually between 30 and 50 years, presenting with progressive cerebellar ataxia, imbalance, and dysarthria. It evolves into other symptoms, such as nystagmus, ophthalmoplegia, lid retraction ("bulging eyes"), diplopia, and slow saccades. In the advanced stages, orthesis usage to assist ambulation is necessary, and the patient then becomes bound to a wheelchair or bedridden. In this stage, severe dysarthria and dysphagia are common. Other phenotypes are also possible, such as dystonia, amyotrophy, fasciculation, and spasticity. Severe cognitive impairment is not common [9-11].

Nowadays, the group of spinocerebellar ataxias (SCAs) is labeled according to the sequence of gene discovery: SCA 1, SCA 2, SCA 3, etc. MJD is the third in this sequence. In the 1990s, the pathogenic variant localized to chromosome 14, and was named MJD1 (now ATXN3), in Japanese families, using highly polymorphic microsatellite DNA polymorphisms [12]. Concomitantly, French families were described to have an SCA thought to be unrelated, SCA 3. Its gene was mapped to the same chromosome of MJD1 [13], and it soon became evident that they were the same disease. In the majority of the countries, SCA 3 is the leading cause of autosomal dominant SCA [14].

Genetically, SCA 3 is caused by CAG repeat expansion on the ATXN3 gene, known as ataxin-3, located in $14 \mathrm{q}$ 32.1, resulting in an expanded polyglutamine [15]. ATXN3 encodes for ataxin-3, which is thought to participate in cellular protein quality control pathways, among other functions, and is ubiquitously expressed in neuronal and nonneuronal tissues. The normal repeat rate is between 12 and 40 (42 in some studies). Repetitions above 55 (52 in some studies) are found in affected patients, and the significant positive correlation between repetition length of CAG and severity of the disease, and the significant negative correlation between repetition length of CAG and disease onset have been well-established [15].

MJD is considered to be a cerebellar and extracerebellar neurodegenerative disease - also involving visual, au- ditory, vestibular, sensory, dopaminergic, and cholinergic systems [16]. In the beginning, even in presymptomatic stages, the first neuroradiological alteration found is cervical spinal atrophy. As the disease evolves, imaging tends to show diffuse cerebral atrophy [17-19].

It has been more than 40 years since the identification, naming, and description of the disease, and the 1972 study is still generally accepted as the first description. Nevertheless, there have been previous descriptions of cerebellar ataxias with an autosomal dominant pattern of inheritance, resembling MJD phenotypically. In this article, the authors present possible earlier descriptions of the condition.

\section{The Drew Family of Walworth}

In 1895, William Gowers (1845-1915; National Hospital for the Paralysed and Epileptics, Queen Square, London, UK) examined a patient named William Drew, and his final diagnostic was paralysis agitans, in the National Hospital (now the National Hospital for Neurology and Neurosurgery). Since then and until recently, many clinician-researchers have examined members of the Drew family of Walworth [20]. With a clear autosomal dominant pattern of inheritance (for details, see Kang et al. [18]) and pleomorphic clinical characteristics among patients (euphoria, emotional instability, and without cognitive impairment; vertical ophthalmoparesis, nystagmus, and lid retraction; pyramidal signs; sensitive disturbances; extrapyramidal manifestations - including parkinsonism; dysarthria; altered control of sphincters; and cerebellar ataxia) [21], the members of the family were examined through decades by others including $\mathrm{T}$. Grainger Stewart, James Collier, Kinnier-Wilson, Aldren Turner, Worster-Drought, Fergunson and Critchley (1929), J. Brown (1975), Anita Harding (1982 and 1984) and Giunti, and Sweeney and Harding (1995) [20]. In 1995, Giunti, Sweeney, and Harding published a study presenting the diagnosis of MJD for the family [20,22].

\section{Marie's Heredocerebellar Ataxia}

In 1893, Pierre Marie (1853-1940), a French neurologist who 24 years later would become professor and head of the Department of Neurology at Paris Medical School, collected cases of familial progressive ataxia described by several authors, distinct from Friedreich's ataxia (FA). The disorder was diagnosed in the Haudebourg family 
[23]. The last case in this family was reported in 1941 by Guillain et al. [24], with clinical and anatomopathological correlations. The age of disease onset was normally in the third and fourth decades of life, clearly with familial pattern of inheritance. He proposed naming this condition as "hérédo-ataxie cérébelleuse," which became famous as heredocerebellar ataxia of Pierre Marie [25]. There has always been some discussion about Pierre Marie's hérédo-ataxie cérébelleuse: Is it a collection of different diseases or a unique entity? One thing is certain: the cases he described are clearly different from FA: late onset of cerebellar ataxia with hereditary transmission, presenting accentuation of deep tendon reflexes, sensory disturbances (pain and tactile hypesthesia in limbs), bone alterations, and ocular symptoms (diplopia, visual field defects, and dyschromatopsia), while some characteristics were similar (gait, speech, and fine movement disturbances). Here, the pathological process is supposed to occur in the cerebellum, as opposed to that of FA, which is primarily spinal [24]. However, later autopsies of Pierre Marie's cases were described and they showed very mild atrophy of the cerebellum, while spinocerebellar tracts and posterior columns of spine were affected [26, 27]. Despite that, on a reappraisal of the last autopsy, Uchihara et al. (2004) [28] concluded that heredocerebellar ataxia of Pierre Marie was consistent with MJD.

Several authors have tried to classify heredocerebellar ataxias. It is noticeable that ataxia diseases were gathered into groups for the first time by Pierre Marie, as cited previously [25]. Once this distinction was not sufficient (FA vs. non-FA), other authors conducted studies in the following years in an attempt of classifying the inherited SCAs. In 1900, Joseph Jules Dejerine (1849-1917; French neurologist) and André-Thomas (1867-1963; French neurologist) [29] introduced the term olivopontocerebellar atrophy (OPCA), but it did not fit for all dominant ataxias and could also aggregate sporadic diseases, for example multiple system atrophy. Gordon Holmes [30] (1876-1965; British neurologist), in 1908, made the first attempt of classification of cerebellar diseases based on pathology and pathogenesis, which was somehow simplistic but was a start in this challenging effort. In 1954, Greenfield [31] (1884-1958; the "father of neuropathology"; the National Hospital, Queen Square, London) proposed the term spinocerebellar degenerations in his monography, and described the disease with a pathological approach, the hereditary diseases of the cerebellum. Konisgmark and Weiner (1970) [32] subdivided OPCA into five subtypes clinically and pathologically. Plaitakis (1978) [33] proposed another clinicopathological study on cerebellar degenerations. In the 1980s, it became evident that neuropathology should not be the guide for providing the classification, and Anita Harding [34, 35] (1952-1995; British neurologist and professor of Clinical Neurology at the Institute of Neurology of the University of London) termed autosomal dominant cerebellar ataxias (1982) and classified this group of diseases into types I-IV (1983), with applicability in live patients. Currently, the most accepted classification is based on genetics, in order of gene discovery.

\section{Schut et al.}

Between 1950 and 1953, these authors published the case of a 343-member family in which 22 examined patients (among 45 members with known ataxia) presented with a heterogeneous phenotypic ataxia. They were divided into four groups: FA, hereditary cerebellar ataxia with normal or diminished deep tendon reflexes, hereditary cerebellar ataxia with increased deep tendon reflexes, and hereditary spastic paraplegia. Cases that were postmortem evaluated showed lesions in the spinal cord (Clarke's column and spinocerebellar tracts), the inferior olives, the middle cerebellar peduncles, and the cerebellar cortex and its efferents [36-39].

\section{Boller and Segarra}

In 1969, François Boller and Jose M. Segarra [40] described a family (the $\mathrm{W}$ family) presenting with progressive ataxia of adult onset. Seventeen members of a 40-member family were affected, in a clear autosomal dominant pattern. Postmortem examination showed spinal, ponto-cerebellar fibers and pontine nuclei involvement, but with the cerebellar parenchyma relatively spared.

Case number 1 was a 52 -year-old person who developed imbalance at age 39 years, who evolved into a bedridden state in the later part of disease progression. No evidence of cardiomyopathy or bone deformity could be found. On neurological examination, he showed upward gaze ophthalmoplegia and nystagmus on lateral gaze. Unfortunately, the cerebellum was damaged during brain removal, which made its examination impossible [40].

Case number 2 was a spastic paraplegic person who developed ataxia and spasticity in 1946. Other findings were tongue tremor, mild cognitive impairment, and urinary and fecal incontinence. Pathological examination 


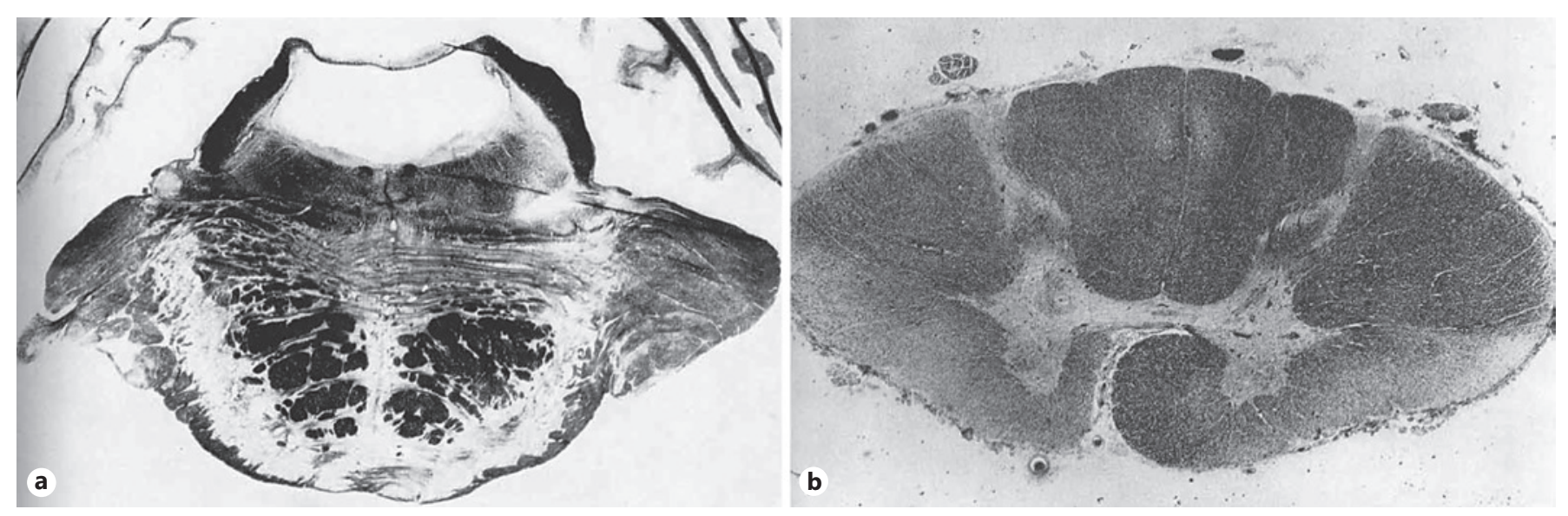

Fig. 1. Photograph of case 2, published by Boller and Segarra (1969), disclosing: normal corticospinal tracts, but with marked atrophy of the pons and middle cerebellar peduncles, which leads to enlargement of the fourth ventricle (a); and cervical spinal cord with pallor in the lateral and anterior columns of the white matter, and also slight pallor in the medial portion of the fasciculus gracilis [32] (b). Reproduced with permission from Eur Neurol. 1969;2(6):356-73. Copyright (C 2019 American Medical Association. All rights reserved.

disclosed a very small pons, with atrophy of the middle cerebellar peduncle and spinal cord (Fig. 1). There was minimal cerebellar atrophy [40].

The authors begin this article discussion by drawing attention to the variabilities presented in these cases: "This family differs clinically and above all pathologically from the 'classical' forms of spino-cerebellar degeneration encountered usually" [40].

In the following years, there were noticeable scientific debates between the authors and Pogacar [41-43], in which correct classification of this family was discussed. At that time, correct classification was impossible to achieve, as the system of classification was messy. In one of those articles - a letter to the editor of the Archives of Neurology, Pogacar [43] presented a brain CT scan of one the members of the $\mathrm{W}$ family described by Boller and Segarra, which showed marked atrophy of the brainstem and cerebellum [43].

The authors have recently tried to gain access to the pathological studies performed by Boller and Segarra in their patients, in order to confirm genetically that they represented a case of MJD; however, unfortunately, the material related to the $\mathrm{W}$ family is no longer available (McKEE A, personal communication to FB, 2018).

Boller and Segarra [44] later wrote a book chapter entitled "Spino-pontine degeneration", in which they discussed the differences between the previous case described by them in 1969 and previous descriptions such as FA, heredocerebellar ataxia of Pierre Marie, cortical cerebellar atrophy, and OPCA. In the beginning of the chapter, they drew attention to their discussion by dividing the cases into 2 main groups: one with predominantly spinal lesions and another with lesions that affect mainly the brain stem and the cerebellum. In the cases of Walworth and Haudebourg families previously described, impairment of conjugate upward gaze was noticed. At the end of this chapter, they drew attention to the pathological similarities between the cases described by Woods and Schaumburg (1972) [2], which in turn would be the wellknown first description MJD, and their previous description in 1969, with the exception of a more severe involvement of the anterior horn cells and substantia nigra [44].

\section{Taniguchi and Konigsmark}

The authors made a description of a 3-generation family, in which among 16 persons affected by a progressive cerebellar ataxia, 6 were studied. The patients seem to present hereditary ataxia with cerebellar and pyramidal tract signs (ataxia, dysarthria, nystagmus, muscle atrophy and weakness, and hyperactive reflexes), and one of them had upward gaze restriction. Necropsy examination was performed in only one affected member of the family, and a unique type of spino-pontine atrophy was found [45].

The pathological findings were neuronal loss in the lentiform and subthalamic nuclei (mild), and substantia nigra (moderate), with marked gliosis of red nuclei. The 


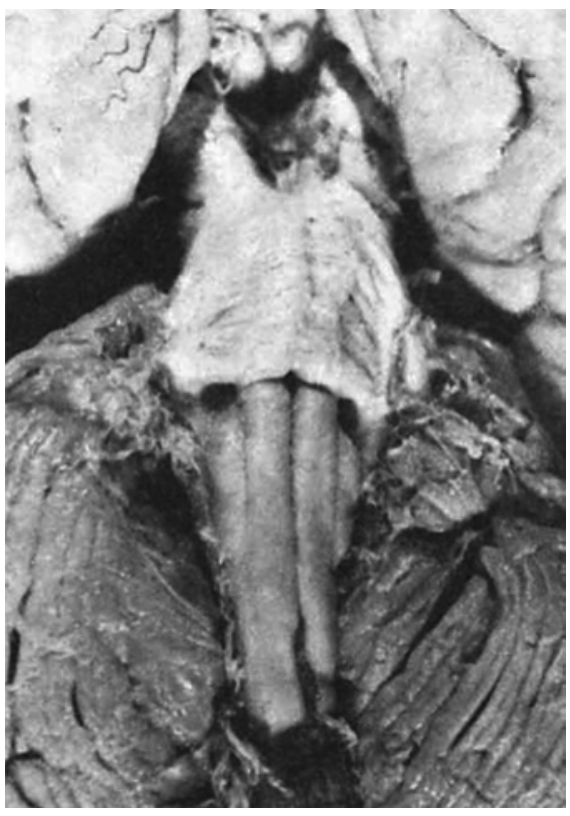

Fig. 2. Atrophy of the pons and middle cerebellar peduncles, in one of the cases published by Taniguchi and Konigsmark (1971) [37]. Reproduced with permission from Journal of Neuropathology \& Experimental Neurology. 1971;30(1):131-2. Copyright (C) 2019 American Medical Association. All rights reserved.

cerebellum was slightly small due to white matter loss, and superior cerebellar peduncles were atrophic. There was loss of nuclei basis pontis. Neuronal loss and gliosis were found in some cranial nerve nuclei, although the inferior olivar nuclei were normal. The spinal cord appeared grossly normal, but microscopical fiber loss in the funiculus gracilis and lateral funiculus was observed. Mild loss of anterior motor horn cells and moderate loss of Clarke's column neurons were observed (Fig. 2) [45].

The authors noticed that this disease could be the same as that previously described by Boller and Segarra (1969) [40]. Also, they suggested that it should be named "dominant spino-pontine atrophy" [45].

Jorge Sequeiros [46] drew attention to the similarity between both cases in 1986, and also suggested for the first time that those descriptions could be the first cases of MJD in the literature. This similarity was previously also observed by Boller and Segarra [44].

\section{Conclusion}

Previous descriptions of hereditary ataxia were made, resembling the heterogeneous phenotypic intra-familiar presentation of MJD, but genetic confirmation was im-

possible at that time. Although the pathological descriptions were very distinct, they could also represent MJD cases. We point out the importance of previous descriptions whose authors made history during the challenging classification of hereditary cerebellar ataxias. We suggest that the condition would best be called dominant spinopontine atrophy.

\section{Acknowledgement}

This article is dedicated to the late José Segarra, MD, and Bruce W. Konigsmark, MD, who would probably be with us developing this article if they were alive.

\section{Statement of Ethics}

The manuscript has been prepared according to the ethical norms of the institute and the journal.

\section{Disclosure Statement}

The authors have no conflicts of interest to declare.

\section{Funding Sources}

There were no funding sources for this work.

\section{Author Contributions}

(1A) Conception and (1B) design of the work; (2A) drafting and (2B) revising the work; (3) final approval. Alex Tiburtino Meira: 1A, 1B, 2A, 2B, 3. José Luiz Pedroso: 1A, 1B, 2A, 2B, 3. François Boller: 1A, 1B, 2A, 2B, 3. Gustavo Leite Franklin: 1B, 2A, 2B, 3. Orlando Graziani Povoas Barsottini: 1A, 1B, 2A, 2B, 3. Hélio Afonso Ghizoni Teive: 1A, 1B, 2A, 2B, 3.

References

Eur Neurol 2020;83:99-104 DOI: $10.1159 / 00050719$
1 Nakano KK, Dawson DM, Spence A. Machado disease. A hereditary ataxia in Portuguese emigrants to Massachusetts. Neurology. 1972;22(1):49-55.

2 Woods BT, Schaumburg HH. Nigro-spinodentatal degeneration with nuclear ophthalmoplegia. A unique and partially treatable clinico-pathological entity. J Neurol Sci. 1972; 17(2):149-66.

3 Rosenberg RN, Nyhan WL, Bay C, Shore P. Autosomal dominant striatonigral degeneration. A clinical, pathologic, and biochemical study of a new genetic disorder. Neurology. 1976;26(8):703-14. 
4 Romanul FC, Fowler HL, Radvany J, Feldman RG, Feingold M. Azorean disease of the nervous system. N Engl J Med. 1977;296(26): 1505-8.

5 Coutinho P, Calheiros J, Andrade C. Sobre uma nova doença degenerativa do sistema nervoso central transmitida de modo autossômico dominante e afectando famílias originárias dos Açores. O Médico. 1977;82: 446-8.

6 Coutinho P, Andrade C. Autosomal dominant system degeneration in Portuguese families of the Azores Islands. A new genetic disorder involving cerebellar, pyramidal, extrapyramidal and spinal cord motor functions. Neurology. 1978;28(7):703-9.

7 Lima L, Coutinho P. Clinical criteria for diagnosis of Machado-Joseph disease: report of a non-Azorena Portuguese family. Neurology. 1980;30(3):319-22.

8 Teive HAG, Arruda WO, Trevisol-Bittencourt PC. Doença de Machado-Joseph descrição de cinco membros de uma família. Arq Neuropsiquiatr. 1991;49(2):172-9.

9 Maruff P, Tyler P, Burt T, Currie B, Burns C, Currie J. Cognitive deficits in Machado-Joseph disease. Ann Neurol. 1996;40(3):421-7.

10 Matsumura R, Takayanagi T, Fujimoto Y, Murata K, Mano Y, Horikawa $\mathrm{H}$, et al. The relationship between trinucleotide repeat length and phenotypic variation in MachadoJoseph disease. J Neurol Sci. 1996;139(1):527.

11 Schöls L, Amoiridis G, Epplen JT, Langkafel M, Przuntek H, Riess O. Relations between genotype and phenotype in German patients with the Machado-Joseph disease mutation. J Neurol Neurosurg Psychiatry. 1996;61(5): 466-70.

12 Takiyama $\mathrm{Y}$, Nishizawa $\mathrm{M}$, Tanaka $\mathrm{H}, \mathrm{Ka}$ washima S, Sakamoto H, Karube Y, et al. The gene for Machado-Joseph disease maps to human chromosome 14q. Nat Genet. 1993;4(3): $300-4$.

13 Stevanin G, Le Guern E, Ravisé N, Chneiweiss H, Dürr A, Cancel G, et al. A third locus for autosomal dominant cerebellar ataxia type I maps to chromosome 14q24.3-qter: evidence for the existence of a fourth locus. Am J Hum Genet. 1994;54(1):11-20.

14 Teive HAG, Camargo CHF, Munhoz RP, Munhoz RP. Reply to comment on: "the geographic diversity of spinocerebellar ataxias (SCAs) in the americas: a systematic review". Mov Disord Clin Pract. 2019;7(2):239-40.

15 Kawaguchi Y, Okamoto T, Taniwaki M, Aizawa M, Inoue M, Katayama S, et al. CAG expansions in a novel gene for Machado-Joseph disease at chromosome $14 \mathrm{q} 32.1$. Nat Genet. $1994 ; 8(3): 221-8$
16 Rüb U, Brunt ER, Deller T. New insights into the pathoanatomy of spinocerebellar ataxia type 3 (Machado-Joseph disease). Curr Opin Neurol. 2008;21(2):111-6.

17 Horimoto Y, Matsumoto M, Akatsu H, Kojima A, Yoshida M, Nokura K, et al. Longitudinal study on MRI intensity changes of Machado-Joseph disease: correlation between MRI findings and neuropathological changes. J Neurol. 2011;258(9):1657-64.

18 Kang JS, Klein JC, Baudrexel S, Deichmann R, Nolte D, Hilker R. White matter damage is related to ataxia severity in SCA3. J Neurol. 2014;261(2):291-9.

19 Yagishita S, Inoue M. Clinicopathology of spinocerebellar degeneration: its correlation to the unstable CAG repeat of the affected gene. Pathol Int. 1997;47(1):1-15.

20 Teive HAG, Arruda WO. A família Drew de Walworth: um século após a avaliação inicial finalmente o diagnóstico doença de Machado-Joseph. Arq Neuropsiquiatr. 2004;62(1): $177-80$.

21 Ferguson FR, Critchley M. A clinical study of an heredo-familial disease resembling disseminated sclerosis. Brain. 1929;52(2):20325.

22 Giunti P, Sweeney MG, Harding AE. Detection of the Machado-Joseph disease/spinocerebellar ataxia three trinucleotide repeat expansion in families with autosomal dominant motor disorders, including the Drew family of Walworth. Brain. 1995;118(5):1077-85

23 Klippel M, Durante G. Contribution a l'etude des affections nerveuses familiales et hereditaires. Rev Med. 1892;12:745-86.

24 Guillain G, Bertrand I, Godet-Guillain J. Etude anatomique d'un cas d'heredo-ataxie cerebelleuse. Rev Neurol. 1941;73:609-11.

25 Marie P Sur l'heredo-ataxie cerebelleuse. Sem Méd. 1893;18:444-7.

26 Barker LF. A description of the brain and spinal cords of two brothers dead of hereditary ataxia. Trans Assoc Amer Physicians. 1903; 18:637-709.

27 Meyer A. The morbid anatomy of a case of hereditary ataxy. Brain. 1897;20(3):276-89.

28 Uchihara T, Duyckaerts C, Iwabuchi K, Iwata $\mathrm{M}$, Yagishita S, Hauw JJ. Was the ataxia of Pierre Marie Machado-Joseph disease? A reappraisal based on the last autopsy case from la Salpêtrière Hospital Arch Neurol. 2004; 61(5):784-90.

29 Dejerine JJ, Thomas A. L'atrophie olivoponto-cérébelleuse. Nouvelle Iconographie Salpêtrière. 1900;13:330-70.
30 Holmes G. An attempt to classify cerebellar disease, with a note on Marie's hereditary cerebellar ataxia. Brain. 1908;30(4):545-67.

31 Greenfield JG. The spinocerebellar degenerations. Oxford: Blackwell; 1954.

32 Konigsmark BW, Weiner LP. The olivopontocerebellar atrophies: a review. Medicine. 1970;49(3):227-41.

33 Plaitakis A. Cerebellar degenerations. Curr Neurol. 1978;7:159-92.

34 Harding AE. The clinical features and classification of the late onset autosomal dominant cerebellar ataxias. A study of 11 families, including descendants of the "the Drew family of Walworth". Brain. 1982;105(Pt 1):1-28.

35 Harding AE. Classification of the hereditary ataxias and paraplegias. Lancet. 1983;1(8334): 1151-5.

36 Schut JW, Böök JA. Hereditary ataxia; difference between progeny of male and female affected members and a definition of certain signs useful in detecting the disease prior to onset of clinical symptoms. AMA Arch Neurol Psychiatry. 1953;70(2):169-79.

37 Schut JW. Hereditary ataxia; a survey of certain clinical, pathologic and genetic features with linkage data on five additional hereditary factors. Am J Hum Genet. 1951;3(2):93-110.

38 Schut JW, Haymaker W. Hereditary ataxia: a pathologic study of five cases of common ancestry. J Neuropathol Clin Neurol. 1951;1(3): 183-213.

39 Schut JW. Hereditary Ataxia: clinical study through six generations. Arch Neurol Psychiatry. 1950;63(4):535-68.

40 Boller F, Segarra JM. Spino-pontine degeneration. Eur Neurol. 1969;2(6):356-73.

41 Boller F, Segarra JM. Dominant spinopontine atrophy. Arch Neurol. 1979;36(4):255.

42 Pogacar S, Ambler M, Conklin WJ, O'Neil WA, Lee HY. Dominant spinopontine atrophy. Report of two additional members of family W. Arch Neurol. 1978;35(3):156, 62.

43 Pogacar S, Finelli PF. Dominant spinopontine atrophy. Arch Neurol. 1983;40(4):259-60.

44 Boller F, Segarra JM. Spino-pontine degeneration, Eur Neurol. In: Vinken P, Bruyn J, editors. Handbook of clinical neurology. Amsterdam: North Holland; 1975. Vol. 2(6); Chap. 18, p. 356-73.

45 Taniguchi R, Konigsmark BW. Dominant spino-pontine atrophy. Report of a family through three generations. Brain. 1971;94(2): 349-58.

46 Sequeiros J, Suite ND. Spinopontine atrophy disputed as a separate entity: the first description of Machado-Joseph disease. Neurology. 1986;36(10): 1408 . 